\title{
Geneza metryki poznańskiej kapituły katedralnej
}

Zarys treści: Artykuł dotyczy uwarunkowań towarzyszących powstania metryki (protokołów posiedzeń) kapituły katedralnej w Poznaniu (zachowanej od 1428 r.). Autor wskazuje przede wszystkim na podejmowane od schyłku XIV w. próby wprowadzenia reform zarządu majątku kapituły, co rodziło potrzebę utrwalania jej postanowień. Decydujące znaczenie dla powstania metryki miało wdrożenie tych reform (1423/1424). W tym samym czasie biskup Andrzej Łaskarz wprowadzał też szereg nowych rozwiązań kancelaryjnych.

\begin{abstract}
The paper discusses the conditions accompanying the founding of the metrica (protocols of meetings) of the Cathedral chapter in Poznań (preserved from 1428). The author points especially to the attempts at reforming the administration of the chapter's estate undertaken from the end of the $14^{\text {th }}$ century, which created the need to record its decisions. The most important cause for starting the metrica was the introduction of those reforms (1423/1424). At the same time bishop Andrzej Łaskarz also introduced several new chancellery solutions.
\end{abstract}

Słowa kluczowe: Poznań, kapituła katedralna, biurokracja, metryka kapituły, akta oficjałów i wikariuszy generalnych

Keywords: Poznań, Cathedral chapter, bureaucracy, chapter metrica, records of officials and vicars general

Początki pisanej rejestracji czynności podejmowanych przez katedralne korporacje kanonickie w polskiej prowincji kościelnej sięgają, jak się przyjmuje, przełomu XIV i XV w. ${ }^{1}$ Akta takie, określane jako metryki kapitulne, w krajach Europy Zachodniej znane są dużo wcześniej². W Polsce najstarsze zachowały się, choć w stanie szczątkowym, z Wrocławia ze schyłku XIV w. ${ }^{3}$ Od 1408 r. rozpoczyna się pierwsza zachowana księga metryki kapituły metropolitalnej w Gnieźnie ${ }^{4}$. Znacznie późniejsze są znane akta czynności kapituł poznańskiej (1428), włocławskiej (1435), krakowskiej (1438)

${ }^{1}$ M. K o c z e r s k a, Kancelarie i dokumentacja kościelna, w: Dyplomatyka staropolska, Warszawa 2015, s. 338-388, zwł. s. 369-370.

${ }^{2}$ Np. w Salisbury od 1329 r. (Hemingsby's Register, wyd. H. M. Chew, Devizes 1963).

3 C. G r ü n h a g e n, Protokolle des Breslauer Domkapitels. Fragmente aus der Zeit 13931460, Zeitschrift des Vereins für Geschichte und Alterthum Schlesiens, 5, 1863, s. 118-159; Acta capituli Wratislaviensis 1500-1562. Die Sitzungsprotokolle des Breslauer Domkapitels in der ersten Hälfte der 16. Jahrhunderts, wyd. A. Sabisch, t. I, Köln-Wien, 1972, s. XLV-XLVI.

${ }^{4}$ Gniezno, Archiwum Archidiecezjalne, sygn. ACap. B 14. 
i płockiej (1437) $)^{5}$, choć ksiądz Józef Nowacki stwierdził, że w Poznaniu protokoły kapituły zaczęto prowadzić już w $1406 \mathrm{r}^{6}{ }^{6} \mathrm{~W}$ każdym razie domniemane początki tych akt budzą wątpliwości. Zdaniem Marii Koczerskiej protokoły kapituły gnieźnieńskiej istniały już wcześniej, na co wskazują adnotacje zamieszczone w pierwszej, bardzo już porządnie prowadzonej księdze tamtejszej metryki ${ }^{7}$ Jednocześnie autorka ta nie ma pewności, czy w Krakowie protokołowano posiedzenia przed 1438 r., skoro zachowane od tego roku akta są bardzo nieporządne, a osobne beneficjum dla notariusza kapituły powołano dopiero w $1454 \mathrm{r}^{8}{ }^{8}$ Bywały więc różne sytuacje, ale w kontekście zachowania się od 1406 r. akt kapituły kolegiackiej w Łęczycy ${ }^{9}$,

${ }^{5}$ Poznań, Archiwum Archidiecezjalne (dalej cyt.: AAP), sygn. CP 28; Metrica capituli Wladislaviensis antiquissima (1435-1518), wyd. A. Gąsiorowski, Kórnik 2001 (CD-Rom); zob. A. Gą s i or ow sk i, Kanonicy włocławscy w najstarszej metryce kapitulnej (1435-1500), w: Duchowieństwo kapitulne w Polsce średniowiecznej i wczesnonowożytnej. Studia nad pochodzeniem i funkcjonowaniem elity kościelnej, Toruń 2000, s. 9-51; Kraków, Archiwum i Biblioteka Kapituły Metropolitalnej, sygn. 1a; Płock, Archiwum Diecezjalne, odpis akt z lat 1437-1445 sporządzony przez ks. W.T. Mąkowskiego (por. I. S k i e r s k a, Źródła do badania praktyk religijnych w średniowiecznej Polsce: akta sądów kościelnych i kapituł, Archiwa Biblioteki i Muzea Kościelne, 87, 2007, s. 190).

${ }^{6}$ J. N o w a c k i, Dzieje archidiecezji poznańskiej, t. I-II, Poznań 1959-1964, tu t. II, s. 168: „w Konsystorzu Poznańskim spisywano bieżąco w osobnych protokolarzach wszelkie sprawy od r. 1403, a w kapitule od r. 1406 począwszy”. Autor nie opatrzył niestety tego stwierdzenia odesłaniem do żadnych źródeł.

${ }^{7}$ M. K o c zers k a, Kancelarie, s. 369, bez powołania się na szczegółowe argumenty źródłowe.

${ }^{8}$ Tamże, s. 369-370; t a ż, Zbigniew Oleśnicki i kościół krakowski w czasach jego pontyfikatu 1423-1455, Warszawa 2004, Aneks I, nr 229. Drugi z argumentów nie jest w pełni przekonujący, bo notariusze kapituły istnieli już wcześniej. Np. w 1389 r. wymienieni są mistrz Stanisław notariusz kapituły i wicekustosz Świętosław notarius ebdomadarum, odpowiedzialny zapewne za notowanie kanoników (wikariuszy?) sprawujących w danym tygodniu msze przy ołtarzu głównym (Rationes Zbignei a Nasięchowice archidiaconi Cracoviensis, wyd. W. Kętrzyński, Monumenta Poloniae historica, t. V, Lwów 1888, s. 922). Notariuszem tej kapituły miał być też Stanisław Ciołek, jak podaje kronika Jana z Komorowa z XVI w. (Monumenta Poloniae historica, t. V, s. 135); pisarstwo to należy chyba cofnąć na lata przed 1410 r., kiedy to Długosz wymienia Stanisława jako notariusza królewskiego (Joannis Dlugossii Annales seu cronicae incliti Regni Poloniae, lib. X-XI, Warszawa 1997, s. 58), a pracę w kancelarii monarszej (z przerwą 1419-1420) trudno raczej byłoby pogodzić z pracą dla kapituły; Z. K o w a 1 s k a, Stanisław Ciołek (zm. 1437). Podkanclerzy królewski, biskup poznański, poeta dworski, Kraków 1993, s. 28, 34, 55, zakłada, że Stanisław pracował w kancelarii królewskiej od ok. 1400 r. Za konsultacje w tej sprawie dziękuję bardzo Panu Prof. Markowi D. Kowalskiemu, który podziela wątpliwości wobec istnienia metryki przed $1438 \mathrm{r}$. Wskazuje on także na to, że w Krakowie późno zostały zebrane statuty tamtejszej kapituły i sporządzony inwentarz jej majątku, a wpisy w najstarszej metryce dotyczą głównie spraw majątkowych. Wszystko to każe przyjąć, że nie istniała starsza metryka (por. M.D. K ow a ls k i, Piętnastowieczne statuty kapituły katedralnej w Krakowie, w: Polska i jej sąsiedzi w późnym średniowieczu, Kraków 2000, s. 233-253; t e nże, Dzieje autografu katedralno-kolegiackiej części „Liber beneficiorum dioecesis Cracoviensis" Jana Długosza, Studia Źródłoznawcze 46, 2008, s. 83-94).

${ }^{9}$ Kraków, Biblioteka Naukowa PAU i PAN, rkps 6558 (tzw. Teki Ulanowskiego); o rachunkach tych zob. A. K o w a ls k a - P i e tr z a k, Wydatki kapituły łęczyckiej na rzecz kolegiaty w świetle not prokuratorów (1406-1419), Acta Universitatis Lodziensis, Folia Historica 72, 2001, s. 43-62, a zwłaszcza I. S k i e r s k a, Ornaty, sierpy, węgiel. O rachunkach łęczyckiej kapituły kolegiackiej w pierwszej połowie XV wieku, w: Ecclesia, cultura, potestas. Studia 
wydaje się, że początki niektórych przynajmniej metryk kapituł katedralnych można przesuwać w głąb XIV w. Skoro bowiem prowadzono metrykę w prowincjonalnym, choć bogatym, kościele kolegiackim, to dlaczego miałoby być inaczej w kapitułach katedralnych współodpowiedzialnych za wybór biskupów, zarząd rozległych diecezji, gospodarkę ich dobrami, erekcję nowych kościołów itd. ${ }^{10}$ Przywołane tu akta kapituły łęczyckiej w swej najstarszej części są wprawdzie głównie rachunkami prokuratorów, ale nie stanowią jednak luźnych kartek i pojedynczych rozliczeń, lecz dokumentację prowadzoną systematycznie. Wydaje się, że na ich powstanie wpływ mogła mieć osobowość nieznanego nam niestety ich autora i ważny moment w dziejach samej instytucji (kończono właśnie odbudowę kościoła kolegiackiego), co często skutkowało wzmożeniem dokumentacji pisanej ${ }^{11}$. Ustalenie początków metryk polskich kapituł wymaga wnikliwych badań nad poszczególnymi przypadkami, przy czym uwzględnić zawsze trzeba kontekst ustrojowy, definiujący działalność danej kapituły, a tym samym jej produkcję aktową.

Studium niniejsze poświęcone jest kapitule poznańskiej, której metryki zachowane są względnie kompletnie od 1428 r., a prowadzone były z postępującą systematycznością ${ }^{12}$. Pierwsza zachowana księga metryki oznaczona jest w Archiwum Archidiecezjalnym sygnaturą CP 28. Składa się z 20 składek papierowych formatu folio fracto $(21$ x $29 \mathrm{~cm})$, liczących od 2 do 14 kart, a w sumie ma 206 kart (ostatnia luźna). Całość została zszyta sznurkami, a jako okładka służy pergaminowa, jednostronnie wyprawiana, bulla papieża Marcina V (1417-1431) dla Jana Furmana z Mchów i Zaniemyśla (zm. 1458) ${ }^{13}$. Zachowane w księdze zapisy (bez noty wstępnej) rozpoczynają się od listopada 1428 r., przy czym pierwszy datowany dokładnie pochodzi z 16 dnia tego miesiąca ${ }^{14}$. Zważywszy na fakt, że jesienne posiedzenia generalne rozpoczynały się w dniu św. Marcina (11 XI), przyjąć można, że brakuje przynajmniej jednej lub kilku kart zapisanych na tej sesji (zakończonej $18 \mathrm{XI})^{15}$.

z dziejów kultury i społeczeństwa. Księga ofiarowana Siostrze Profesor Urszuli Borkowskiej OSU, Kraków 2006, s. 169-184, która wskazała (s. 170-171), że rękopis ten jest „tworem sztucznym" złożonym przez B. Ulanowskiego z fragmentów protokołów z posiedzeń kapituły łęczyckiej z lat 1433-1452 oraz rachunków prokuratorów tej korporacji.

${ }^{10}$ Warto w tym miejscu zauważyć, że zachowały się, choć w stanie szczątkowym, rachunki (rejestr wydatków) kapituły krakowskiej z końca XIV w. (Rationes Zbignei a Nasięchowice), a kolejne znane są z 1514 r. (M. K o c z e r s k a, Rachunki kapituły krakowskiej z początku XVI w. - analiza zawartości pierwszej zachowanej księgi, w: Świat średniowiecza. Studia ofiarowane Henrykowi Samsonowiczowi, Warszawa 2010, s. 258-275).

${ }^{11}$ T. J u re k, Pierwsze wieki historii Łęczycy, w: Początki Łęczycy, Łódź 2014, t. III, s. 99. Zob. uwagi M. S ł on i a, Średniowieczne rachunki szpitali wrocławskich, Kwartalnik Historyczny 105, 1998, nr 2, s. 17-32, tu s. 25, 30-32.

12 Dla XV w. są to następujące akta: AAP, CP 28 (1428-1439), 29 (1442-1461), 30 (14611475), 31 (1475-1489), 32 (1489-1499). Brakuje kart z ostatnich miesięcy życia biskupa Ciołka, ale wypisy z tego fragmentu zawiera sumariusz kanonika Zymchanowskiego (AAP, CP 13, k. 14-15).

${ }^{13}$ O nim: P. D e m b ińs ki, Poznańska kapituła katedralna schyłku wieków średnich. Studium prozopograficzne 1428-1500, Poznań 2012 (dalej cyt.: DembPozn.), s. 416-420. Bulla została przycięta przy oprawianiu tomu metryki i nie można odczytać daty jest wystawienia.

${ }^{14}$ AAP, CP 28, k. 2.

15 Tamże, k. 3. 
Kart tych nie znał już kanonik Mateusz Zymchanowski, który w końcu XVIII w. dokonywał wypisów z tej księgi ${ }^{16}$. Warto tu nadmienić, że rozpoczęcie wpisów do zachowanej księgi CP 28 zbiega się z objęciem diecezji poznańskiej przez Stanisława Ciołka, który do Poznania zjechał właśnie na listopadową kapitułę ${ }^{17}$.

Próżno szukać najbliższych kilku posiedzeń kapituł partykularnych - pierwsze odnotowane zostało dopiero 17 XII 1428 r., kiedy to dzień przed kolejnym, nadzwyczajnym posiedzeniem generalnym kapituła wybrała swoich prokuratorów ${ }^{18}$. Od świąt Bożego Narodzenia 1428 r. zapisywane już były z mniejszą lub większą częstotliwością sprawy załatwiane na kolejnych posiedzeniach partykularnych 20 i 28 XII 1428, a potem 4 i 19 I, 1 II, 22 III $^{19}, 20$, 24 i 31 V, 21 i 26 VI, potem zaś następuje seria wpisów z kilkudniowego posiedzenia generalnego po św. św. Piotrze i Pawle (1-5 VII $)^{20}$. Dalsze wpisy z posiedzeń partykularnych tego roku pochodzą z 20 i 23 VIII, 24 IX, 22 i 29 X oraz 8 XI, po czym następują liczne wpisy z jesiennej kapituły generalnej po św. Marcinie (12-18 XI) ${ }^{21}$. Taka praktyka w miarę częstego odnotowywania spraw załatwianych na posiedzeniach partykularnych w zasadzie nie koresponduje ze zwyczajem kapituły metropolitalnej w Gnieźnie, która w zachowanych od $1408 \mathrm{r}$. aktach rejestrowała początkowo tylko sprawy z posiedzeń generalnych ${ }^{22}$; podobnie było we Włocławku, gdzie rejestrowano głównie czynności podejmowane na posiedzeniach generalnych, a wpisy z posiedzeń partykularnych były rzadkie ${ }^{23}$. Sama częstotliwość wpisów w metryce, nieograniczających się do decyzji podjętych na kapitułach generalnych, może sugerować, że zwyczaj odnotowywania powziętych na posiedzeniach decyzji był wypracowywany już od pewnego czasu. Jednak obserwacja formularza wpisów zdaje się tego nie poświadczać. Formularz ten nie jest bowiem jeszcze ustabilizowany. Nie każdy zapis otwiera lista uczestniczących w posiedzeniu prałatów i kanoników ${ }^{24}$. Kolejność wymienianych na tych listach prałatów (poza prepozytem i dziekanem) bywa dość dowolna, podobnie jak kanoników, niewymienianych konsekwentnie według stażu zasiadania $\mathrm{w}$ stallach ${ }^{25}$. W tym sensie

\footnotetext{
${ }^{16}$ AAP, CP 13; Biblioteka Kórnicka PAN, rkps 1510.

${ }_{17}$ T. J u r e k, Biskupstwo poznańskie w wiekach średnich, Poznań 2018, s. 331.

${ }_{18}$ W metryce błędna datacja: piątek 19 grudnia (tamże, k. 5); tego dnia wypadała niedziela, musiało więc chodzić o 17 grudnia.

${ }^{19}$ Między k. 11 i 12 brak przynajmniej jednej karty, na której mogło być odnotowane posiedzenie między 1 II a 22 III $1429 \mathrm{r}$.

20 Tamże, k. 8-18v.

${ }^{21}$ Tamże, k. $18 \mathrm{v}-25$.

${ }^{22}$ M. C z y ża k, Kapituła katedralna w Gnieźnie w świetle metryki z lat 1408-1448, Poznań 2003, s. 408.
}

${ }^{23}$ A. G ą s i or ow s k i, Kanonicy włocławscy, s. 24 n.

${ }^{24}$ Np. AAP, CP 28, k. 8 (28 XII 1428 r.: in loco capitulari venerabilis vir dominus Nicolaus [Kicki] archidiaconus Gneznensis cum dominis prelatis et canonicis ad sonum campane capitulariter congregatis; 20 XII 1428 r.: in loco capitulari venerabiles et honorabiles viri, domini Johannes cantor, Nicolaus [Sumiński] scolasticus, Jacobus [Wygonowski Starszy] archidiaconus Pczeviensis, magister Strzeszko [z Ułanowa] ac alii prelati et canonici; k. 9 (4 I 1429 r.: in loco capitulari venerabilis magister Vincencius Coth ac alii prelati ac canonici ad sonum campane capitulariter congregati).

${ }^{25}$ Np. tamże, k. 7 (18 XII 1428, data: sobota 20 XII jest błędna, bo był to poniedziałek) podani kolejno: kanonik Mikołaj Kicki archidiakon gnieźnieński, kanclerz Mikołaj z Górki, 
wpisy nie są sformalizowane, choć zdecydowana większość z nich odnotowuje dzień, godzinę oraz miejsce zebrania kanoników.

Spektrum spraw odnotowywanych na pierwszych stronach metryki jest dość szerokie. Mamy tu zatem kwestie związane z dyscypliną podległego kapitule kleru ${ }^{26}$, organizacją przestrzeni Ostrowa Tumskiego ${ }^{27}$, zgodą na odbycie synodu diecezjalnego ${ }^{28}$, uchwalanymi statutami ${ }^{29}$ czy przyjęciem przysięgi od nowego kanonika ${ }^{30}$. Podkreślić jednak należy, że zdecydowanie przeważająca liczba not dotyczy spraw majątkowych korporacji. Związane były one z wprowadzaniem w życie uchwalonego kilka lat wcześniej statutu o wyrównaniu dochodów z prebend prałackich i kanonickich. Polegało to na uśrednieniu i ujednoliceniu pensji wypłacanej co roku kanonikom i (nieco wyższej) prałatom oraz przeznaczeniu wygospodarowanych tym sposobem nadwyżek na refekcje wypłacane członkom kapituły rezydującym przy katedrze $^{31}$. Kapituła określała zatem wartość taksy odprowadzanej z dóbr prebendalnych (przejmowanych kolejno do wspólnego zarządu), wysokość wypłacanych pensji, a także innych należnych jej opłat, jak czynszów z wsi prestymonialnych czy taks z nowo obejmowanych kurii kanonickich ${ }^{32}$. W metryce zapisywano także sprawy związane z majątkiem po zmarłych kanonikach (np. Mirosławie z Bytynia) ${ }^{33}$,

kanonicy Janusz z Wszołowa, mgr Strzeszek [z Ułanowa], Paweł z Czechowa, archidiakon pszczewski Jakub Wygonowski [Starszy], kanonicy Bogusław Świnka oficjał warszawski, Paweł z Czechowa [ponownie!], Hektor z Koziemina [Starszy] prepozyt głuszyński, Maciej Korzbok oficjał [generalny], scholastyk Mikołaj Sumiński, kanonicy mgr Wincenty Kot, Piotr z Nowca, Mikołaj Słupek syn Bronisza [z Budzisławia], Maciej z Tarnowy.

${ }^{26}$ Dnia 17 XII 1428 r. kapituła rozsądzała spór między wikariuszami wieczystymi a rektorem szkoły katedralnej dotyczący zakresu obowiązków uczniów szkoły związanych ze śpiewem podczas mszy w katedrze (tamże, k. 6).

${ }^{27}$ Np. 31 V 1429 r. kanonik Florian z Poklatek na prośbę kapituły ustąpił z części działki, na której położona była jego kuria kanonicka, w celu wytyczenia drogi do szkoły katedralnej (tamże, k. 13).

${ }^{28}$ Tamże, k. 14v (1 VII 1429).

29 Tamże, k. 21 (15 XI 1429, statut o sprawozdaniach finansowych prokuratorów).

30 Tamże, k. 14 (Stanisław Latowski), 15 (Władysław Oporowski przez prokuratora).

31 Statut uchwalony został 17 XI 1423, a zatwierdzony i skorygowany przez biskupa Andrzeja Łaskarza 7 II 1424 r. (Kodeks dyplomatyczny Wielkopolski, t. I-XI, wyd. I. Zakrzewski, F. Piekosiński, A. Gąsiorowski, Poznań 1877-1999 - dalej cyt.: KDW, tu t. V, nr 377, 386); reformę tę omawia DembPozn. s. 45-49.

${ }^{32}$ Np. AAP, CP 28, k. 3 (cesja części kurii Albryka z Modły na rzecz Macieja z Tarnowy), 5 (wybór prokuratorów kapituły, decyzja w sprawie rozliczeń z wsi prestymonialnych wakujących po zmarłym Mirosławie z Bytynia), 8v-9 (nadanie Wincentemu Kotowi z Dębna wsi Janikowo, oszacowanie jej dochodów, zgoda na zatrzymanie przez Wincentego wsi Niesłabin, ustalenia dotyczące jego refekcji), 11 (decyzja, by prokuratorzy przejęli dochody z prebend po zmarłych Pawle z Kłodawy i Pawle z Czechowa), 11v (nadanie Mikołajowi Kickiemu wsi Stęszewko i rozliczenia z tym związane), 13-13v (oszacowanie dóbr we wsiach prestymonialnych wakujących po zmarłym Mikołaju Kickim, ustalenie taksy z nich), 14 (nadanie wsi prestymonialnych wakujących po Kickim Wojciechowi Jastrzębcowi, Wincentemu Kotowi i Jaśkowi z Czechla), k. 15v (statut o określeniu wysokości pensji wypłacanych członkom kapituły), k. 17-17v (decyzja o wyznaczeniu komisji, która określi wysokość taksy z prebendy objętej przez Władysława Oporowskiego).

${ }_{33}$ Tamże, k. 10. 
a szczególne miejsce zajmowały te dotyczące rozliczeń z biskupem Stanisławem Ciołkiem z zarządu dóbr biskupich w okresie sediswakancji ${ }^{34}$.

W tych wczesnych wpisach uwidacznia się charakter metryki jako księgi prowadzonej przede wszystkim dla rejestracji spraw dotyczących administracji majątkiem. Pozwala to przynajmniej w przybliżeniu wskazać na okres, w którym przypadają jej początki. Punkt wyjścia wyznacza, jak sądzę, pontyfikat biskupa Jana Kropidły (1382-1383/84), kiedy to kapituła podjęła 7 X 1383 r. próbę pozbawienia prepozyta prawa do rozdawania wsi prestymonialnych i przejęcia kontroli nad dochodami z dóbr prebendalnych przez całą korporację ${ }^{35}$. Próba ta, choć zapewne nieudana (jak wskazuje kolejna suplika kapituły z 1395 r. dotycząca redukcji słabo uposażonych prebend w kapitule) ${ }^{36}$, zakończyła się jednak prawdopodobnie ustanowieniem pewnej kontroli kapituły nad swym majątkiem, a w każdym razie nad decyzjami pierwszego prałata, co sprzyjać musiało pojawieniu się pomysłu rejestracji rozdawnictwa prestymoniów. Potwierdza to przykład sąsiedniej kapituły gnieźnieńskiej, gdzie początek zachowanej metryki (1408) zbiega się w czasie z burzliwym procesem o prawo do dysponowania wsiami prestymonialnymi ${ }^{37}$. Zauważmy, że o ile dokument prepozyta Trojana i kapituły z 1 VII 1383 r. sporządził podpisujący się tylko jako notariusz publiczny Maciej Blida z Poznania (późniejszy kanonik) ${ }^{38}$, o tyle kilkanaście lat później (1399-1404) pojawił się już specjalny notariusz kapituły, Maciej z Gwiazdowa (notariusz publiczny, wikariusz wieczysty, adwokat konsystorski, a potem wicedziekan), występuje on jednak także w dokumentach biskupa Wojciecha Jastrzębca $^{39}$. Warto zwrócić uwagę, że biskup ten wraz z kapitułą podjął wysiłek przebudowy katedry i starał się wzbogacać kulejącą liturgię katedralną, w związku z czym nadał w 1403 r. kanonikom liczne dziesięciny przeznaczone na refekcje dla rezydujących prałatów i kanoników ${ }^{40}$. To też były momenty istotne dla funkcjonowania kapituły, utwierdzały bowiem konieczność egzekwowania należnych kapitule pieniędzy od licznych dzierżycieli prestymoniów, co zapewne wzmacniało przeświadczenie o potrzebie rejestracji pewnych spraw, np. ewentualnego podziału dochodów z poszczególnych wsi czy sposobu egzekucji (pobór, dzierżawa, sprzedaż) i zagospodarowania dziesięcin. Wszystko są to jednak tylko przesłanki sprzyjające prowadzeniu dokumentacji czynności majątkowych (powstaniu metryki kapitulnej), ale żadna z nich nie ma oczywiście rangi rozstrzygającej. $Z$ drugiej strony zauważmy

${ }^{34}$ Np. tamże, k. 12v (24 V 1429, kanonik Florian z Poklatek, którego biskup skwitował z zarządu klucza dolskiego, prosi o sporządzenie w tej sprawie instrumentu notarialnego).

${ }^{35}$ KDW III, nr 1813; por. DembPozn. s. 29; T. J u r e k, Biskupstwo, s. 411-412.

${ }^{36}$ Bullarium Poloniae, t. III, wyd. I. Sułkowska-Kuraś, S. Kuraś, Rzym 1988, nr 422, gdzie m.in. prośba o zatwierdzenie zmiany polegającej na pozbawieniu prepozyta prawa do nadawania wsi prestymonialnych; zob. DembPozn. s. 29, 37-38.

${ }^{37}$ M. C z y ż a k, Kapituła, s. 163.

${ }^{38}$ KDW III, nr 1811.

39 Jako notariusz i pisarz kapituły: KDW V, nr 7, 39 (dokument biskupi), VI, nr 371 (dokument biskupi), VII, nr 525, 563; por. też KDW III, nr 1903, V, nr 128, 138, VII, nr 509, 679. Osobny problem stanowi istnienie specjalnej prałatury kanclerskiej, powołanej w początku XIV w. dla kanclerza biskupiego (DembPozn. s. 23-24, 33-34; T. J u r e k, Biskupstwo, s. 475-484).

${ }^{40} \mathrm{KDW}$ V, nr 39, 106; Bullarium Poloniae, t. III, nr 1101; zob. T. J u r e k, Biskupstwo, s. 323. 
bowiem, że wystawienie przez kanoników poznańskich 19 VIII 1407 r., w związku z zaognionym sporem kleru i szlachty o dziesięciny, dokumentu zobowiązującego wszystkich członków kapituły do wzajemnej obrony przed grabieżcami ${ }^{41}$, wydaje się wskazówką, że nie istniała jeszcze księga, do której można by wpisać tego rodzaju zobowiązanie, a jeśli istniała, to dla samych kanoników nie miała większej rangi. Później wspólne interesy korporacji zabezpieczano przez składanie przez jej członków przysięgi na zachowanie statutów, w tym najistotniejszego o wyrównaniu dochodów $\mathrm{z}$ prebend, co odnotowano właśnie w metryce ${ }^{42}$.

Za przełomowe wydarzenie, skutkujące zmianą czy rozwinięciem procedur biurokratycznych, uznać trzeba z pewnością uchwalenie w latach 1423/1424 przez kapitułę wspomnianego już statutu o wyrównaniu dochodów z prebend. Statut ten wymuszał bowiem bardzo ścisłą kontrolę uposażenia i zarządu poszczególnych prebend oraz ścisłe określanie taks, jakie miały wpływać z dóbr prebendalnych do wspólnego skarbca, z którego wypłacano następnie ujednolicone pensje oraz refekcje. Wymagało to nie tylko prowadzenia odrębnych i rozbudowanych rachunków (nie są one zachowane, bo traciły aktualność wraz z dokonaniem rozliczenia), ale w ogóle rozbudowy dokumentacji pisanej. Jest zresztą znamienne, że już w latach 1419-1422 sporządzono papierowy (dziś niezachowany) inwentarz dochodów poszczególnych prebend kapituły poznańskiej ${ }^{43}$, prawdopodobnie nie bez związku z przygotowywaną reformą. W 1423 r. został on przepisany do osobnej pergaminowej (również niezachowanej dziś) księgi zwanej inventarius pergameneus, a w 1536 r. Metrica seu inventarius proventuum aut liber beneficiorum, praelaturarum et canonicatuum ac prebendarum ecclesie cathedralis Poznaniensis ${ }^{44}$. Z tej pergaminowej księgi powstał

${ }^{41}$ KDW V, nr 112; analogiczny dokument krakowski: Kodeks dyplomatyczny katedry krakowskiej ś. Wacława, wyd. F. Piekosiński, t. II, Kraków 1883, nr 496; o kontekście sprawy zob. M. B o b r z y ń s k i, Wiadomość o uchwałach zjazdu piotrkowskiego z r. 1406 oraz takiegoż zjazdu z r. 1407, Rozprawy Akademii Umiejętności, Wydział Historyczno-Filozoficzny 1, 1874, s. 111-116; B. U l a n ow s k i, Zjazdy piotrkowskie z r. 1406-1407 i ich uchwały, tamże 21, 1888, s. 330-332; A. P r o c h a s k a, Konfederacja ziemian przeciw duchowieństwu w 1407 r., Kwartalnik Historyczny 21, 1907, zwł. s. 299-304; R. G r o d e c k i, O konfederacjach duchowieństwa w Polsce średniowiecznej, Roczniki Dziejów Społecznych i Gospodarczych 15, 1953, s. 299-311, zwł. s. 307. Wystawianie tych dokumentów przez kanoników sugeruje, że obawiano się o ich postawę, jako że pochodzili przeważnie z rodzin szlacheckich. Dokument poznański zasługuje z pewnością na nowe wydanie krytyczne i opracowanie.

${ }^{42} \mathrm{~Np}$. wikariusz generalny Jan Drzewicki złożył 11 V 1434 r. protest, ponieważ Jan Niewieski nie chciał zaprzysiąc statutów kapitulnych, a w szczególności statutu o wyrównaniu dochodów z prebend. Dopiero 30 VI 1434 r. Jan Niewieski wraz ze swym bratem, kantorem poznańskim Mikołajem, na polecenie kapituły złożyli wymaganą przysięgę (AAP, CP 28 k. 132v, 135).

${ }^{43}$ Inwentarz ten istniał jeszcze w 13 XI 1454 r., kiedy to kanonik Stanisław syn Marcina z Dobieszewa pozwał archidiakona Mikołaja Głębockiego i kanonika Hektora z Koziemina o jego okazanie przed biskupem poznańskim Andrzejem Bnińskim. Wieczorem tego samego dnia Hektor przyniósł do kurii biskupiej spisany na papierze w formie dutki (longe figure) inwentarz i odczytano z niego uposażenie prebendy kanonickiej fundi Kórnik z czasów, gdy posiadał ją Mikołaj Strosberg, który zmarł w 1419 r. (AAP, sygn. AE I, k. 215v-216).

${ }^{44}$ Akta kapituł z wieku XVI wybrane, wyd. B. Ulanowski, t. I, cz. 1, Kraków 1908, nr 81. Według ks. J. Nowackiego, na podstawie tego właśnie inwentarza kanonik (Klemens) Drzewicki dochodził swych praw do danin ze wsi Gać. Inwentarz ten istniał jeszcze w końcu XVI w., 
w latach 1488-1492 odpis inwentarza prebend kapitulnych, włączony z czasem do założonej w 1500 r. księgi Revisiones bonorum episcopatus et capituli Posnanien$\mathrm{sis}^{45}$. Według J. Nowackiego inventarius pergameneus miał pozostawać pod opieką każdorazowego notariusza (sekretarza) kapituły wraz z protokołami jej posiedzeń i pieczęcią mniejszą ${ }^{46}$. Notariusze kapituły dysponowali zresztą nie tylko protokołami z posiedzeń, ale w ogóle dokumentacją potrzebną przy administracji dóbr.

W późniejszych tomach metryki, prowadzonej z coraz większą dokładnością, zachowały się zapisy dotyczące przekazywania tych materiałów kolejnym notariuszom. Przyjętemu na to stanowisko 18 XII 1460 r. Stanisławowi synowi Wita z Kłecka kapituła wręczyła pieczęć, metrykę, siedem innych ksiąg oraz statuty prowincjalne ${ }^{47}$. Stanisław ustąpił z urzędu (zmarł?) przed 12 VII 1465 r., decyzję o wyborze nowego notariusza odwlekano jednak aż do jesiennej kapituły generalnejes. Dopiero 12 XI 1465 r. przyjęto na wakujące stanowisko Piotra syna Mikołaja z Kobylnik. Otrzymał on, obok pieczęci i metryki, „siedem innych ksiąg”49. Kolejnym notariuszem został 13 V 1480 r. Jakub z Szamotuł pleban w Ryczywole i wikariusz wieczysty w katedrze poznańskiej, jednak stosowna zapiska nie zawiera wzmianek o przejętych przez niego księgach $^{50}$. Przyjętemu 6 VII 1495 r. notariuszowi Ambrożemu wręczono 10 ksiąg z metrykami, statutami i inwentarzem oraz pieczęć $c^{51}$, natomiast zatrudniony ponownie rok później Jakub z Szamotuł dostał „do wiernych rąk” pieczęć, metrykę i innych dziewięć ksiąg wraz z inwentarzem i statutami ${ }^{52}$. Gdy 29 III 1497 r. kapituła pozbawiła Jakuba stanowiska i powołała na nie Arnolda z Kuchar, wspomniano jedynie, że otrzymał on pieczęć, metrykę i klucz do szafy, w której przechowywane były pozostałe księgi ${ }^{53}$. Wzmianki o liczbie ksiąg metryki nie zawiera także zapiska z 23 XI 1499 r., dotycząca przyjęcia na notariat wikariusza wieczystego Jana z Obornik ${ }^{54}$.

Zestawione zapisy dotyczące liczby ksiąg przekazywanych notariuszowi kapitulnemu, a zwłaszcza najwcześniejszy z nich (1460), należy odnieść nie do samej metryki,

kiedy to wypożyczył go kanonik Hieronim Powodowski (Księga uposażenia diecezji poznańskiej z roku 1510, wyd. J. Nowacki, Poznań 1950, s. 1-2, por. s. 34-35; DembPozn. s. 797).

${ }_{45}$ AAP, CP 111, k. 46-53; zob. Księga uposażenia, s. 2-3.

${ }^{46}$ Księga uposażenia, s. 2-3.

${ }^{47}$ Acta capitulorum nec non iudiciorum ecclesiasticorum selecta, t. I-III, wyd. B. Ulanowski, Kraków 1894-1908, tu t. I, nr 546 (AAP, CP 29, k. 231v): sigillumque, metricam et alios libros VII in numero computatos simul statutis provincialibus fideliter reservanda manualiter tradiderunt.

${ }^{48}$ AAP, CP 30, k. 49v, 52.

49 Acta capitulorum, t. I, nr 596 (AAP, CP 30, k. 56): sigillumque, metricam et alias septem libros in numero fideliter servanda tradiderunt - - in presencia - - domini Andree Dei gracia episcopi Poznaniensis.

${ }^{50}$ AAP, CP 31, k. 40.

${ }^{51}$ Acta capitulorum, t. I, nr 851 (AAP, CP 32, k. 87v): sibi decem metriculas librorum cum statutis et inventario ac sigillo causarum ad servandum commiserunt et manualiter tradiderunt.

${ }^{52}$ Acta capitulorum, t. I, nr 861 (AAP, CP 32, k. 115-115v): sigillum, metricam et alios novem libros cum inventario et statutis fideliter servanda tradiderunt.

${ }_{53}$ AAP, CP 32, k. 136v-137: sigillum, metricula et clavem ad alios libros capitulares in almario contentos tradiderunt.

${ }^{54}$ Wspomniano natomiast o szafie, w której przechowywane były księgi (AAP, CP 33, k. 2v). 
ale do różnych materiałów, którymi dysponował notariusz. Przypuszczać należy, że wchodziły tu w grę wspomniane już inwentarze (papierowy z 1422 i pergaminowy z 1423 r.), najstarszy kopiariusz biskupstwa z ok. 1420 r. (tzw. Liber privilegiorum B, obecna sygn. CP 2), wreszcie osobno wymieniana księga ze statutami prowincjalnymi (chodzi o statuty wieluńsko-kaliskie Mikołaja Traby). Do tego dochodziły zachowane do dzisiaj księgi metryk kapitulnych (dziś sygn. CP 28 i 29), a z czasem także zwód statutów kapitulnych z 1463 r. ${ }^{55}$, wreszcie kolejny kopiariusz (tzw. Liber privilegiorum $C$, obecna sygn. CP 3). Trudno powiedzieć czy można zaliczyć do tego zbioru kopiariusz kolegium wikariuszy katedralnych tzw. Iura vicariorum (dziśs sygn. CP 10) ${ }^{56}$. Istotne jest przy tym, że liczby „tomów” są czysto orientacyjne, bo nie znamy sposobu oprawienia tych akt w XV w. Mogły być bowiem przechowywane wyłącznie w składkach, luźno owijanych w obwoluty ${ }^{57}$, tak jak do końca XV w. działo się zapewne z aktami czynności biskupich Andrzeja Bnińskiego ${ }^{58}$. Na temat innych ksiąg pozostających w gestii notariusza kapituły można tylko spekulować. Wiadomo, że biskup Andrzej Łaskarz nakazał prowadzenie protokołów z podejmowanych przez siebie czynności ${ }^{59}$, co sugeruje, że zaprowadzono w tym celu osobną serię akt. Być może protokoły takie prowadzono także za Stanisława Ciołka. Nie wiadomo jednak, czy księgi te, dziś nieznane, w ogóle trafiły do skarbca katedralnego lub raczej biblioteki kapitulnej, czy też do odrębnie z czasem prowadzonego archiwum biskupa i konsystorza generalnego ${ }^{60}$. W początku XVI w. księgi biskupie były przechowywane we dworze biskupim w Ciążeniu, zanim zostały oddane do biblioteki ${ }^{61}$.

Pewne uzupełnienia rysującego się obrazu początków metryki kapitulnej przynoszą zapiski dotyczące czynności kapituły, wnoszone do ksiąg poznańskich

${ }^{55}$ Spisany w 1463 r. zwód statutów kapitulnych został włączony do kodeksu zawierającego statuty Mikołaja Trąby i oprawionego w XV w. (Statuty synodalne wieluńsko-kaliskie Mikołaja Trąby z r. 1420, wyd. B. Ulanowski, J. Fijałek, A. Vetulani, Kraków 1915-19201951, s. XXX; Statuta capitulorum Gneznensis et Poznaniensis ecclesiarumque collegiatarum Varsoviensis et Lanciciensis, wyd. B. Ulanowski, w: Archiwum Komisji Prawniczej, t. V, Kraków 1897, s. 455 n.).

56 Według T. J u r k a, Biskupstwo, s. 482, 490, wikariusze katedralni mieli osobne archiwum, choć nie wiadomo, czy własnego notariusza. Kolegium wikariuszy podlegało jednak kapitule, a miejscem przechowywania najcenniejszych dokumentów obu instytucji był prawdopodobnie skarbiec lub biblioteka katedralna.

${ }^{57}$ Nie sposób wypowiedzieć się na temat pierwotnej oprawy ksiąg CP 28, 29 i 30; dwie ostatnie najpewniej wtórnie oprawione zostały z skórę przed 18 XII $1860 \mathrm{r}$.

${ }^{58}$ J. N o w a c k i, Biskup Andrzej Bniński w walce z husytami Zbąszynia. Nieznane karty z procesów husyckich roku 1439, Roczniki Historyczne 10, 1934, z. 2, s. 250; A. K o z a k, Zapiski z akt czynności biskupich Andrzeja Łaskarza, w: Memoria viva. Studia historyczne poświęcone pamięci Izabeli Skierskiej (1967-2014), Warszawa-Poznań 2014, s. 479-480.

59 Tamże, s. 476-486.

${ }^{60} \mathrm{O}$ archiwum biskupim zob. J. N o w a c k i, Dzieje, t. I, s. 339, 559 n., z którego informacji (s. 562, 564-565) wynika jednak, że wyodrębnione zostało ono dopiero w XVI w.; w innym miejscu (tamże, t. II, s. 168) podaje on zresztą, że księgi biskupów Andrzeja Bnińskiego i Uriela Górki złożono w 1506 r. w bibliotece kapituły. W każdym razie nadzór nad księgami biskupimi aktualnie urzędującego ordynariusza niewątpliwie sprawował jego kanclerz (T. J u r e k, Biskupstwo, s. 483-497).

${ }^{61}$ J. N o w a c k i, Dzieje, t. II, s. 168; T. J u r e k, Biskupstwo, s. 489. 
oficjałów generalnych i wikariuszy. Księgi te zachowały się od $1403 \mathrm{r}^{62}$, przy czym nas najbardziej zainteresują akta $\mathrm{z}$ lat poprzedzających zachowaną metrykę, a więc oficjałów Bogusława Świnki (1417-1422) i Macieja Korzboka (1423-1431) ${ }^{63}$. Są tam wpisywane sprawy, które później odnotowywano z zasady w metryce. Najważniejsze z nich dotyczą rejestracji posiedzeń kapituły w księgach oficjalskich. Pierwsza pochodzi z akt oficjała Bogusława Świnki. Dnia 7 X 1420 r. zapisano, że obecni na posiedzeniu (partykularnym) kapituły wymienieni imiennie kanonicy, pod przewodnictwem wikariusza generalnego Bartłomieja Rynka i oficjała Bogusława (obaj byli kanonikami), rozpatrzyli sprawę karną o kradzież przez kleryka Szczepana z Brześćca (na Mazowszu) pieniędzy, kosztowności, bielizny, ubrań, książek i dokumentów ze skrzyni należącej do poznańskiego wikariusza wieczystego Mikołaja Barana ${ }^{64}$. Sprawa podlegała kapitule, ponieważ to ona sprawowała jurysdykcję nad niższym klerem katedralnym, a rzecz działa się na Ostrowie Tumskim, gdzie kapituła była gospodarzem. Notę wpisano jednak do akt oficjała, być może z uwagi na zastosowaną tu formalną procedurę związaną z przesłuchaniem oskarżonego, co samo w sobie jest jednak pewnym ewenementem jeśli chodzi o księgi oficjałów poznańskich $\mathrm{z}$ tego czasu. Drugi przykład pochodzi z 21 X 1424 r., kiedy to do akt Macieja Korzboka (także kanonika katedralnego) wciągnięty został protokół (poprzedzony listą obecnych na posiedzeniu) wyboru posłów kapituły na zjazd ze szlachtą w Gnieźnie, gdzie obradować miano o sposobie opłacania dziesięcin ${ }^{65}$.

Kolejne przykłady związane są z kompetencjami prałatów - dziekana kapitulnego do nadzoru nad kolegium wikariuszy wieczystych oraz prepozyta do przydzielania kurii kanonickich. W dniu 28 VIII 1425 r. przed oficjałem Maciejem Korzbokiem rozpatrywano spór o ustalenie legalności prezenty udzielonej Adamowi ze Stępocina na wikarię wieczystą w katedrze poznańskiej przez kanonika Janusza z Wszołowa, którego dziekan katedralny Piotr z Kobylina pozwał o niezgodne z prawem korzystanie z pełnomocnictwa (udzielonego mu przez kanonika Macieja Chłapowskiego). Była to więc sprawa w zasadzie podlegająca wyłącznym kompetencjom kapituły i jej dziekana ${ }^{66}$, stąd dziwić może fakt, że rozpatrzono ją przed oficjałem. Mogło to oczywiście wynikać z narosłych w trakcie sporu emocji lub też ze szczególnych prerogatyw udzielonych oficjałowi Maciejowi Korzbokowi przez biskupa Andrzeja Łaskarza (nie znamy aktu nominacyjnego). Wykluczone w każdym razie, by strony dobrowolnie zgodziły się na sąd oficjała, gdyż w zapisce mowa jest wprost o pozwie ${ }^{67}$.

${ }^{62}$ AAP, sygn. AC 1-12, z lat 1403-1411, 1417-1421, 1423-1429.

${ }^{63}$ O nich: J. N o w a c k i, Dzieje, t. II, s. 229; DembPozn. s. 376-377.

${ }^{64}$ AAP, AC 4, k. 164v: Item venerabiles et honorabiles viri, domini Bartholomeus tamquam vicarius in spiritualibus, Boguslaus canonicus et officialis Poznaniensis, Hector prepositus Gluschinensis, Florianus, Miroslaus de Bithin, Janussius de Szolowo, Nicolaus Lanthman, Simon de Kaczkowo et Slupko de Schamotuli requisiverunt eum [Szczepana z Brześćca], ut poneret caucionem fideiussoriam de parendo iuri, qui respondit, quod non haberet, sed ut ipsum non iudicaverint secundum exigenciam operum suorum, sed secundum misericordiam ipsorum, et prefati domini capitulariter congregati ipsum ex confessatis suis carceri deputaverunt.

${ }_{65}$ Acta capitulorum, t. II, nr 978.

${ }^{66}$ DembPozn. s. 30.

67 AAP, AC 8, k. 196v: In causa domini Petri decani Poznaniensi cum domino Janussio canonico, Curek retulit, quia dominum Janussium ad instanciam domini Petri decani ad 
Z kolei 17 XI 1425 r. również w księdze oficjała Macieja Korzboka odnotowano zapis poruszający dwie kwestie, po pierwsze nadanie przez prepozyta Wojciecha Jastrzębca kurii kanonickiej kanonikowi Mikołajowi Kozłowskiemu, następnie zaś ustanowienie przez prepozyta pełnomocnika w celu nadawania na przyszłość domów kanonickich i udzielania prezenty na beneficja, nad którymi posiadał patronat (czyli m.in. na kanonie katedralne!). Czynności te miały miejsce najpewniej jeszcze w czasie trwania jesiennego posiedzenia generalnego kapituły, najpewniej już po zakończeniu sobotnich obrad, kiedy to podjęto decyzję o przekazaniu wspomnianego w zapisce domu. Były to formalnie czynności niesporne i dotyczące wyłącznie samej korporacji. W późniejszym okresie informacje o nadaniu kurii kanonickich stanowiły bardzo krótkie noty w metryce kapituły, do których zazwyczaj dołączano wzmianki o należnej kapitule taksie za ich nadanie. Tym razem wpisano je jednak do akt oficjała Korzboka, który nie został tu zresztą w ogóle wymieniony jako świadek czynności ${ }^{68}$. Wniesienie tego zapisu wynikało, jak sądzę, z postawy wikariusza Mikołaja Sikory, zapewne niechętnego, by wydać dom Kozłowskiemu. Sugeruje to specjalne podkreślenie w zapisce, że klucze do kurii wydał on dobrowolnie i zgodził się na

hodiernam diem citavit, quo citato et comparente idem dominus decanus verbo proposuit, quomodo nuper defuncto olim Ni(colao) Lubinski vicario perpetuo in ecclesia Poznaniensi idem dominus Janussius non habito pleno mandato domini Mathie Schlapowski canonici Poznaniensis, qui habet ad dictam vicariam presentare, quendam Adam de Stampoczino clericum Poznaniensis diocesis presentavit illis, qui mandatum non habuerunt, dictum Adam presentatum instituendi et investiendi ad dictam vicariam, petivit igitur compelli dictum dominum Janussium canonicum ad producendum mandatum huiusmodi, si quid habet, alias ipsum puniri ut falsum procuratorem. Dominus autem Janussius dixit, quod dictum Adam habito pleno mandato vicedecano presentavit legittime ad vicariam predictam, de qua est per dictum vicedecanum investitus et installatus. Dominus vero decanus dixit, quod potestatem vicedecano datam revocavit, ita quod ipso existente in diocesi nullum investiret, nisi habito mandato speciali. Dominus vero M. officialis et vicarius in spiritualibus mandavit dicto domino Janussio canonico, ut mandatum huiusmodi, si quid habet, ad horam vesperorum coram ipso vel in absencia sui coram ipso domino decano produceret vel de eodem doceret legittime. Dominus autem Janussius mox propter artacionem termini protestatus de gravamine et appellando, et ibidem dominus Petrus decanus mandavit ex officio suo dicto Adam tamquam illegitime instituto, ut presentacionem, mandatum, investituram et alia munimenta sua in hora vesperorum produceret, de quo Adam est solempniter protestatus etc.

${ }^{68}$ AAP, AC 8, k. 244: hora vesperorum in hostio domus olim domini Nicolai Lubinski perpetui vicarii in ecclesia Poznaniensi in Summo Poznaniensi site, venerabilis vir dominus Albertus prepositus Poznaniensis aperta sibi dicta domo per dominum Martinum Szicora etc. venerabili magistro Nicolao Cozlowski sacre theologie professori, canonico Poznaniensi, de qua sibi alias providerat, possessionem realem et actualem eiusdem domus per mortem dicti olim domini Nicolai Lubinski vacantis, cum effectu assignavit clavesque easdem recipiens eidem magistro Cozlowski tradidit et presentavit in signum vere et pacifice possessionis, dicto domino Martino Szicora presente et non contradicente ymmo consenciente et domum ipsam aperiente ac claves sponte dante, presentibus dominis Nicolao de Kiky etc. canonico et vicario in spiritualibus Poznaniensi, Barthconi Rinconis et Janussio de Scholowo, magistro Strzeschconi canonicis et Nicolao vicecustode, Petro decani et Alberto plebano in Manczniki perpetuis vicariis in ecclesia Poznaniensi predicta etc. Et ibidem dominus Albertus prepositus predictus constituit in suum procuratorem dominum Ni(colaum) Manschporek presentem ad presentandum ad beneficia eadem sub collacione sua etc. ac ad conferendum domos etc., ut in forma meliori, promittens ratum, gratum, presentibus quibus supra. 
jej przekazanie. Chodziło pewnie o spektakl z wręczaniem kluczy Kozłowskiemu w obecności jego kolegów z kapituły, z czego sporządzono protokół, by wpisać go do obdarzonej wiarą publiczną księgi oficjała.

Zastanowienia wymagają też zapisy dotyczące nadzoru korporacji nad szkołą katedralną. Dnia 28 V 1426 r. do ksiąg oficjała wniesiono notę o sprawie Andrzeja rektora szkoły katedralnej, ciętego nożem przez Mikołaja Kota domownika (familiaris) kanonika poznańskiego Mirosława z Bytynia; wpisano też zeznanie złożone przez Andrzeja ${ }^{69}$. Sprawę tę rozsądzali wspólnie wikariusz generalny Mikołaj Kicki i oficjał Maciej Korzbok. Najpewniej uznano, że z uwagi na charakter karny sprawa powinna być rozpatrywana przez tych urzędników w trybie przyjętym dla procesu kanonicznego. Podobnie rozpatrywana była sprawa rektora Andrzeja i uczniów szkoły katedralnej z Janem rektorem szkoły św. Marii Magdaleny w Poznaniu; ich zatarg rozsądzał 16 XII 1427 r. w kapitularzu katedry Mikołaj Kicki jako administrator diecezji ${ }^{70}$. Co ciekawe, wytoczoną rok później przez wikariuszy katedralnych sprawę o powinności uczniów szkoły tumskiej, którzy mieli uświetniać nabożeństwa swym śpiewem, rozsądziła kapituła w swym gronie, z czego sporządzono odpowiednią notę $\mathrm{w}$ istniejącej już wówczas metryce kapitulnej ${ }^{71}$.

W kontekście naszych rozważań bardzo interesujące są zapisy dotyczące obsady konkretnych prebend kanonickich. Była już mowa o zapisanym 17 XI 1425 r. w księgach oficjała udzielonym przez prepozyta pełnomocnictwie m.in. do prezentowania na prebendy ${ }^{72}$. Zapiska z 30 VII $1427 \mathrm{r}^{73}$ porusza natomiast problem zaginionej dokumentacji związanej z prebendą kanonicką fundi Glinka, którą po zmarłym (w 1422 r.) Szymonie z Kaczkowa objął Zbigniew Oleśnicki, a po jego promocji na biskupstwo - niewymieniony tu Andrzej z Sarnowy ${ }^{74}$. Akta te, a przynajmniej ich część, przechowywane były przez prowadzącego sprawę adwokata konsystorskiego Mikołaja Raciąża, który je stracił. Jego oświadczenie wciągnięte zostało, podobnie jak w wypadku innych wymienionych wyżej przykładów, do akt oficjała jako ksiąg wiary publicznej, mimo że kwestia dokumentacji związanej z objęciem prebendy dotykała najżywotniejszych interesów kapituły. Co interesujące, w księdze oficjała

\footnotetext{
${ }^{69}$ AAP, AC 9, k. 132.

${ }^{70}$ AAP, AC 10, k. $264 \mathrm{v}$.

${ }_{71}$ Zob. wyżej, przyp. 26.

72 Zob. przyp. 68.

${ }^{73}$ AAP, AC 10, k. 167v: circumspectus magister Nicolaus de Raczanschk advocatus consistorii Poznaniensis asserens se notarium cause acceptacionis, possessionis prebende domini Sbignei quondam prepositi sancti Floriani in Cracovia, nunc vero episcopi Cracoviensis, que per obitum bone memorie domini Simonis de Caczcowo in ecclesia Poznaniensi vacabat, litteris compulsoriis de curia Romana emanatis pro omnibus actis acticatis et scriptis, si que haberet, suum iuramentum corporale ad sancta Dei Evangelia prestitit, quod prothocolla in causa prebende eiusdem non habet, asserens quod quodam casu inopinato sibi sunt deperdita, presentibus - - .

${ }^{74}$ AAP, AC 2, k. 120v; AE I, k. 46v, gdzie jako posiadacze prebendy wymienieni Szymon z Kaczkowa i Andrzej z Sarnowy. Kolejnym posiadaczem był przypuszczalny krewny Andrzeja, Władysław z Sarnowy (DembPozn. s. 365, 703, 758; P. D e m b i ń s k i, Poznańska kapituła katedralna w czasach Andrzeja Łaskarza, w: Andrzej Łaskarz - dyplomata, duchowny 1362-1426, Konin 2015, s. 49, 60).
} 
Korzboka próżno szukać dalszego ciągu tej sprawy. Z kolei zapis z 5 VII 1428 r. dotyczy dochodzenia w sprawie królewskich uprawnień do kanonii poznańskiej posiadanej przez Dobiesława (Dobiegniewa) z Kołudy, krewnego biskupa nominata poznańskiego Mirosława z Brudzewa, po którym Kołudzki objął tę prebendę. I to była kwestia o kluczowym znaczeniu dla korporacji. Z tej sprawy również mamy w księdze oficjała jedną tylko zapiskę z $1428 \mathrm{r} .{ }^{75} \mathrm{~W}$ aktach z lat następnych sprawy w tak istotny sposób dotyczące kapituły katedralnej już się nie pojawiają. Liczne zapisy odnoszące się do prałatów i kanoników poświęcone są głównie ich zobowiązaniom lub procesom o należności. Są to zatem kwestie podlegające kompetencji sądu konsystorskiego. Brak już natomiast wpisów dotykających ustroju korporacji, protokołów z posiedzeń, kwestii obsady prebend itd. - sprawy te pojawiają się odtąd w zachowanej od jesieni 1428 r. metryce kapituły ${ }^{76}$. Istotne jest zarazem i to, że spraw tego rodzaju nie widać także w pierwszych czterech zachowanych księgach oficjałów i wikariuszy generalnych z lat 1403-1411, 1417-1423, 1417-1418 (dziś sygn. AC 1-3a).

Przytoczone wyżej przykłady pokazują z jednej strony, że potrzeba rejestracji pewnych istotnych dla kapituły czynności pojawiła się dopiero z początkiem lat dwudziestych XV w., z drugiej natomiast, że dla ich upamiętnienia szukano miejsca w księgach oficjałów i wikariuszy generalnych. Nie stanowi to jeszcze jednoznacznie dowodu, że nie istniała wówczas żadna postać zapisów prowadzonych przez samą kapitułę - dla których powstania przyczynę upatrywałem w ustaleniach ustrojowych i majątkowych z lat 1423/1424. Zmiany te pociągały za sobą potrzebę rozbudowy dokumentacji, co wpisywało się zresztą w ogólniejszy trend narastania kościelnej biurokracji. Wysiłki zespołu ludzi powołanego przez biskupa Andrzeja Łaskarza owocowały reformą organizacyjną sądu konsystorskiego (zwiększającą jego efektywność), inwentaryzacją dochodów kanoników i wikariuszy katedralnych, spisywaniem kopiariuszy, zaprowadzeniem protokołów czynności biskupich ${ }^{77}$. Mieściłoby

${ }^{75}$ AAP, AC 11, k. 105: In causa domini Wladislai regis Polonie cum domino Dobegnew canonico Poznaniensi, magister Andreas Cucla oblata citacione petivit restitui privilegium sub tytulo regie maiestatis Regni Polonie, in quo continetur ius patronatus et presentandi dicti domini regis Polonie canonicatus et prebende, que olim dominus Miroslaus de Brudzewo, dum in humanis ageret, possidebat, in quo eciam privilegio collatio ecclesie parochialis in Nakel et super fertonibus in villa Szirnycze continetur, quod privilegium dixit scire vel habere ipsum dominum Dobeslaum, super quo canonicus contestatus est litem --dominus vero recepto a prefato canonico corporali iuramento, quod ipsum privilegium non habet nec habuit neque scit habentem sed neque vidit ipsum, ab impeticione dicti domini regis (absolvit), presentibus --.

76 Wątpliwości budzić może sprawa oskarżenia Andrzeja rektora szkoły katedralnej w Poznaniu (zatem duchownego podległego kapitule i scholastykowi) o pobicie i poranienie kleryka Mikołaja Szymonowego. Sprawę pierwotnie rozpatrywał wikariusz generalny Wincenty Kot z Dębna, który odesłał ją 29 VIII 1429 r. do rozpatrzenia oficjałowi Maciejowi Korzbokowi (AAP, AC 12, k. 136v). Nie znam wyniku tej sprawy, która z pozoru dotyczy wyłącznie kleru tumskiego. Dwa tygodnie później (12 IX) do konsystorza wpłynęła skarga Andrzeja na tegoż kleryka Mikołaja Szymonowego z Poznania o poranienie, co sugeruje, że Mikołaj próbował na własną rękę dochodzić sprawiedliwości (tamże, k. 144v).

77 Zob. A. K o z a k, Dokumenty biskupa poznańskiego Andrzeja Łaskarza. Rekonesans badawczy, w: Andrzej Łaskarz - dyplomata, duchowny 1362-1426, Konin 2015, s. 73-98, zw1. s. 96-97. 
się w tym znakomicie także założenie metryki z protokołami z posiedzeń kapituły. Przypuszczać jednak można, że z początku zapisywano w niej tylko najważniejsze sprawy, przede wszystkim dotyczące majątku kapitulnego i biskupiego, podejmowane na posiedzeniach generalnych. Prawdopodobnie w metryce zaczęto też odnotowywać recepcje na prebendy, być może fakt złożenia przysięgi przez kandydata, a zapewne też udzielenie absolutorium prokuratorom kapituły ${ }^{78}$. Zebrane przykłady z ksiąg konsystorskich wskazują, że z wieloma innymi kategoriami spraw nadal nie wiedziano, co począć, a metryka - o ile rzeczywiście istniała - była traktowana jako zapiski prowadzone na własny użytek, pozbawione charakteru publicznego. Od reform biskupa Łaskarza narastało w każdym razie poczucie konieczności dokładniejszego dokumentowania czynności kapituły. Potrzeba ta pogłębiła się niewątpliwie w okresie burzliwej sediswakancji po śmierci biskupa Andrzeja Łaskarza (1426-1428) i konfliktu biskupa nominata Mirosława z Brudzewa z królem Władysławem Jagiełłą oraz postulowanym przez niego na biskupstwo Stanisławem Ciołkiem ${ }^{79}$. Znamienne jest, że metryka zachowana jest obecnie właśnie od momentu objęcia diecezji jesienią 1428 r. przez Ciołka, z którym stosunki kapituły od początku były złe, a stawały się co raz gorsze ${ }^{80}$. $Z$ pewnością podejmowane przez biskupa próby rozbicia oporu kanoników i podporządkowania ich sobie przyczyniały się do tym staranniejszego dokumentowania podejmowanych decyzji. Odpowiedź na pytanie, kto postanowił założyć metrykę, pozostaje jednak bez odpowiedzi. Raczej to krąg inspiratorów, w którym wymienić można dziekana Piotra z Kobylina (jednego z inicjatorów reformy majątkowej), a najpewniej też Mikołaja Kickiego (administratora diecezji w trudnych latach 1426-1428). Biurokratyczny sukces, jakim było powstanie omawianej tu księgi, miał zapewne wielu ojców, a narodziny metryki w formie, którą znamy od $1428 \mathrm{r}$., trwać musiały przynajmniej kilka lat.

\section{BIBLIOGRAFIA}

Bobrzyński M., Wiadomość o uchwałach zjazdu piotrkowskiego z r. 1406 oraz takiegoż zjazdu z r. 1407, Rozprawy Akademii Umiejętności, Wydział Historyczno-Filozoficzny 1, 1874.

Czyżak M., Kapituła katedralna w Gnieźnie w świetle metryki z lat 1408-1448, Poznań 2003.

Dembiński P., Poznańska kapituła katedralna schyłku wieków średnich. Studium prozopograficzne 1428-1500, Poznań 2012.

Dembiński P., Poznańska kapituła katedralna w czasach Andrzeja Łaskarza, w: Andrzej Łaskarz - dyplomata, duchowny 1362-1426, Konin 2015.

Gąsiorowski A., Kanonicy włocławscy w najstarszej metryce kapitulnej (1435-1500), w: Duchowieństwo kapitulne w Polsce średniowiecznej i wczesnonowożytnej. Studia nad pochodzeniem i funkcjonowaniem elity kościelnej, Torun 2000.

Grodecki R., O konfederacjach duchowieństwa w Polsce średniowiecznej, Roczniki Dziejów Społecznych i Gospodarczych 15, 1953.

${ }^{78}$ Pod 15 XI 1429 r. wpisano postanowienie kapituły (statutum) o wymogu złożenia przez starych (ustępujących) prokuratorów sprawozdania z przychodów i wydatków przed wymienionymi imiennie kanonikami (AAP, CP 28, k. 21-21v), co sugeruje, że wcześniej wymóg taki nie miał charakteru normy ogólnej.

79 Ostatnio T. J u r e k, Biskupstwo, s. 328-330.

${ }^{80}$ J. N ow a c k i, Dzieje, t. II, s. 83-84; Z. K o w a 1 s k a, Stanisław Ciołek, s. 89 n.; T. J u r e k, Biskupstwo, s. 330-333. 
Grünhagen C., Protokolle des Breslauer Domkapitels. Fragmente aus der Zeit 1393-1460, Zeitschrift des Vereins für Geschichte und Alterthum Schlesiens 5, 1863.

Jurek T., Biskupstwo poznańskie w wiekach średnich, Poznań 2018.

Jurek T., Pierwsze wieki historii Łęczycy, w: Początki Łęczycy, Łódź 2014, t. III.

Koczerska M., Kancelarie i dokumentacja kościelna, w: Dyplomatyka staropolska, Warszawa 2015.

Koczerska M., Rachunki kapituły krakowskiej z początku XVI w. - analiza zawartości pierwszej zachowanej księgi, w: Świat średniowiecza. Studia ofiarowane Henrykowi Samsonowiczowi, Warszawa 2010.

Koczerska M., Zbigniew Oleśnicki i kościół krakowski w czasach jego pontyfikatu 14231455, Warszawa 2004.

Kowalska Z., Stanisław Ciołek (zm. 1437). Podkanclerzy królewski, biskup poznański, poeta dworski, Kraków 1993.

Kowalska-Pietrzak A., Wydatki kapituły łęczyckiej na rzecz kolegiaty w świetle not prokuratorów (1406-1419), Acta Universitatis Lodziensis, Folia Historica 72, 2001.

Kowalski M.D., Dzieje autografu katedralno-kolegiackiej części „Liber beneficiorum dioecesis Cracoviensis" Jana Długosza, Studia Źródłoznawcze 46, 2008.

Kowalski M.D., Piętnastowieczne statuty kapituły katedralnej w Krakowie, w: Polska i jej sąsiedzi w późnym średniowieczu, Kraków 2000.

Kozak A., Dokumenty biskupa poznańskiego Andrzeja Łaskarza. Rekonesans badawczy, w: Andrzej Łaskarz - dyplomata, duchowny 1362-1426, Konin 2015.

Kozak A., Zapiski z akt czynności biskupich Andrzeja Łaskarza, w: Memoria viva. Studia historyczne poświęcone pamięci Izabeli Skierskiej (1967-2014), Warszawa-Poznań 2014.

Nowacki J., Biskup Andrzej Bniński w walce z husytami Zbąszynia. Nieznane karty z procesów husyckich roku 1439, Roczniki Historyczne 10, 1934, z. 2.

Nowacki J., Dzieje archidiecezji poznańskiej, t. I-II, Poznań 1959-1964.

Prochaska A., Konfederacja ziemian przeciw duchowieństwu w 1407 r., Kwartalnik Historyczny $21,1907$.

Skierska I., Ornaty, sierpy, węgiel. O rachunkach łęczyckiej kapituły kolegiackiej w pierwszej połowie XV wieku, w: Ecclesia, cultura, potestas. Studia z dziejów kultury i społeczeństwa. Księga ofiarowana Siostrze Profesor Urszuli Borkowskiej OSU, Kraków 2006.

Skierska I., Źródła do badania praktyk religijnych w średniowiecznej Polsce: akta sądów kościelnych i kapituł, Archiwa Biblioteki i Muzea Kościelne 87, 2007.

Słoń M., Średniowieczne rachunki szpitali wrocławskich, Kwartalnik Historyczny 105, 1998, nr 2.

Ulanowski B., Zjazdy piotrkowskie z r. 1406-1407 i ich uchwały, Rozprawy Akademii Umiejętności, Wydział Historyczno-Filozoficzny 21, 1888.

\section{The origins of the metrica of the cathedral chapter in Poznan}

\section{Summary}

The metrica (protocols of meetings) of the chapter in Poznan are preserved from November 1428. The author links their origins to the attempts at reforming the administration of the chapter's estate, earlier the duty of the provost, undertaken from the end of the $14^{\text {th }}$ century. Those reforms were intended to strengthen the chapter's control over its estates and created the need for keeping documentation. The rule of bishop Andrzej Łaskarz (1414-1426) was of key importance in the process, because he introduced several new chancellery solutions, as is well known. From 1420 inscriptions concerning certain activities of the chapter appear in the records of officials and vicars general. This shows that the metrica did not function then in the form known later. The immediate reason for founding the metrica was most probably the 
introduction of the reform of administering the chapter's estate, which started in 1423/1424. The need for registering all the activities undertaken at the meetings must have grown during the stormy arguments between the next bishop Mirosław of Brudzew (1426-1427) and king Ladislaus Jagiello, and later during the rule of bishop Stanisław Ciołek (1428-1437), usually conflicted with the chapter. 